\title{
Consumer Preferences In Purchasing Packaged Meatball Products
}

\author{
A Case Study of Wonokromo Traditional Market, Surabaya
}

\author{
Syarif Imam Hidayat, Pawana Nur Indah, Meilia Zakiyah Darojah Hayati, Laksmi Diana ${ }^{1}$ \\ Agribusiness Department \\ Universitas Pembangunan Nasional "Veteran" Jawa Timur \\ Surabaya, Indonesia \\ ${ }^{1}$ laksmibudiana@gmail.com
}

\begin{abstract}
Increased consumption of meat consumers supports consumer patterns including consumption of processed meat. The purposes of this study are (1) Identifying consumer characteristics of several packaged meatball products in the study area (2) Analyzing consumer ratings based on the performance of the packaged meatball attributes. Site selection is done intentionally in January 2017. With Accidental Sampling. Data processing in this study uses descriptive analysis, and Important and Performance Analysis (IPA). The results of the analysis of the characteristics of respondents are mostly female, Student / Muslim Student, aged between 17-24 years with an income of Rp. 1,000,001 - Rp. $3,000,000$, their last education were high school / vocational school. Based on the calculation of the IPA spread over several quadrants. Quadrant II for Yikko meatballs, KJM "Kijang Mas" and AJ namely Taste, Elasticity and Price. In quadrant III namely Yikko meatballs such as halal certification and composition. In quadrant IV, the Quality for Yikko products and Halal Certification, Composition and quality for $\mathrm{KJM}$ "Kijang Mas" products and Halal Certification, Composition and Quality for AJ Products.
\end{abstract}

Keywords: Packaged beef meatball, Importance Value

\section{INTRODUCTION}

The many cases of meatballs that still contain food that is not suitable for consumption, such as wild boar, pork and alum are happening in the community. Surprisingly, the presence of packaged beef meatballs that have halal labels but positively contain pork. As reported in www.news.detik.com on December 14, 2012 about an article entitled (subtitled) "Wow There are Halal MUI Labeled Meatballs Containing Pork" happened at Pasar Puri and Kopro Market in West Tomang, Jakarta. The merchant said they did not know at all about clear information about the products they sold. But the shocking prices offered by packaged meatball products called Planeateria 56 brand produced by PT Usaha Food, Tangerang, Banten have relatively expensive price than other beef meatball products. Another case about meatballs was on the www.kompas.com page with the title of the article "Bogor Police Caught 7
People Related to Meat Pork Meatballs" on May $30^{\text {th }}$, 2017, explaining that in the Citeureup region, Bogor Regency became a place to make meatballs or pork meatballs and sold in several regencies in Bogor. Of the various cases that have happened, they made consumers feel unsure about any packaged beef meatball products sold in local market. As well as the need for accuracy for consumers to see the condition of the packaging, the material contained and most importantly, the halal-ness of the product in terms of the manufacturing process to packaging and the materials used. Food is the most basic human need, so food availability for the community must always be guaranteed. In the development of civilization society to meet the quality of advanced, independent, in an atmosphere of peace, and prosperous physically and mentally life, the provision of adequate, quality and even food is demanded.

The processed meat industry is one of the industries engaged in animal husbandry. In 2009, the domestic meat industry experienced an average production growth of 10 to 15 percent. This was accompanied by increasing of demand and changing lifestyles of people who turn to fast food. The market potential of processed meats such as meatballs, nuggets, smoked beef and sausages is very large both inside and outside the country. According to [1], who is the chairman of the Indonesian Meat Processing Industry Association (National Meat Processor Association (NAMPA), that the turnover of the meat processing industry reached IDR 1 trillion per year with 75 tons of beef and chicken per day.

The development of consumer knowledge of the product to be purchased includes several characteristics that must be fulfilled by the producer. This is a demand for complete and clear information on the product to be purchased which can include the brand, quality, nutrition and halal-ness of the product.

The study took 3 types of packaged beef meatballs in the Wonokromo traditional market, i.e: Yikko, KJM "Kijang Mas" and AJ. The purpose of this study was to determine the characteristics of packaged meatballs consumers and to determine the relation between variables and preferences 
and to find out which attributes are considered important by consumers in the Wonokromo traditional market.

\section{RESEARCH METHOD}

The sampling technique is done by Non Probability Sampling, through the Accidental Sampling method, which is sampling when the event occurs. This technique is carried out by taking a case or respondents who were available, i.e anyone who accidentally meet with the researcher, can be used as a sample [2].

Roscoe in [2], the sample size is feasible in the study is between 30 to 500. In accordance with this amount, the number of samples used in this study is 40 people. With the criteria of respondents as follows

a. Buy and consume packaged meatballs at least once

b. For self consumption and not for re-sale

Data analysis uses descriptive analysis, IPA (Important Performance Analysis).

Analysis of the data using Important Performance Analysis mathematically as follows: Depreciation of the results is done by using a score. The formula for the level of importance and level of implementation is as follows (Supranto, 2003):

$$
\mathrm{X}=\frac{\sum X i}{n} \quad \text { and } \quad \mathrm{Y}=\frac{\sum Y i}{n}
$$

Where :

$X=$ the average weight of the performance rating of the product attribute

$\mathrm{Y}=$ average weight rating of customer interests

$\mathrm{n}=$ number of respondents

Furthermore, the results of the IPA calculation are presented in a Cartesian diagram with IV quadrant. Supranto (2003) suggests the meaning of each quadrant in the diagram of Importance Performance Analysis is as follows:

1. Quadrant I (Attributes to Improve)

This quadrant shows elements or attributes which importances are above average, but got minor attention from the management so that the level of performance is under the average performance, so that it is less satisfying to the consumer.

2. Quadrant II (Maintain Performance)

This quadrant shows elements or attributes that are considered by consumers above average and implemented well, the performance is above average so that consumers are satisfied.

3. Quadrant III (Attributes to Maintain)

This quadrant shows elements or attributes that are carried out mediocre by the management and are not considered important by consumers.

4. Quadrant IV (Attributes to de-emphasize)

This quadrant shows elements or attributes that are not considered important by the consumer that is carried out very well by management as something that may be very excessive.

Data analysis using descriptive analysis and Chi-Square Test. Mathematically Chi-Square analysis is formulated as follows:

$$
\mathrm{X}^{2}=\sum_{i=1}^{k}\left(\frac{f 0-f h}{f h}\right)^{2} \quad \text { (Priyatno, 2010) }
$$

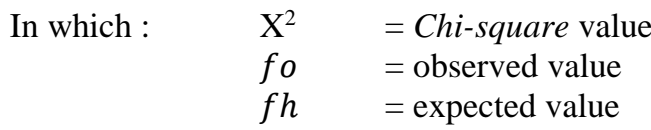

In the confidence coefficient of 95 percent and the real level of 5 percent, the criteria to draw conclusions.

If $\quad$ Sign $\leq 0.05=$ accept Ha refuse Ho

Where :

Sign $\geq 0.05=$ refuse Ha, accept Ho

Ho $=$ The meatball attribute has no relation with the preference of the packaged meatball consumers at the Wonokromo Traditional Market, Surabaya

$\mathrm{Ha}=$ The meatball attribute has a relationship with the preference of meatball consumers at the Wonokromo Traditional Market in Surabaya.

\section{RESULTS AND DISCUSSION}

\section{A. Consumer Characteristics of Packaging Beef Meatballs}

Based on the results of the study it is found that in Table 1, Table 2 and Table 3 describe the characteristics of packaged meatballs consumers by sex. The results show that most consumers are female. So that the decision making regarding the consumption of packaged meatballs is currently dominated by women.

TABLE I. RESPONDENTS' CHARACTERISTICS OF YIKKO MEATBALL BASED ON GENDER

\begin{tabular}{|c|c|}
\hline Gender & Percentage \\
\hline Male & 6 \\
Female & 94 \\
\hline Total & 100 \\
\hline
\end{tabular}

TABLE II. RESPONDENTS' CHARACTERISTICS OF KJM "KIJANG MAS" MEATBALL BASED ON GENDER

\begin{tabular}{|c|c|}
\hline Gender & Percentage \\
\hline Male & 13 \\
Female & 87 \\
\hline Total & 100 \\
\hline
\end{tabular}

TABLE III. RESPONDENTS' CHARACTERISTICS AJ MEATBALL BASED ON GENDER.

\begin{tabular}{|c|c|}
\hline Gender & Percentage \\
\hline Male & 12 \\
Female & 88 \\
\hline Total & 100 \\
\hline
\end{tabular}


Table 4, Table 5 and Table 6 present the characteristics of packaged beef meatball consumers based on age. That, most meatball consumers' ages between 17-24 years. With a percentage of 38, 56 and 43 percent for each packaged meatball product Yikko, KJM "Kijang Mas" and AJ. At this age is a mature enough in making a decision to purchase packaged meatballs to be consumed. That age group is classified as productive age group so that they are more selective in purchasing packaged meatballs.

TABLE IV. RESPONDENTS' CHARACTERISTICS YIKKO MEATBALL BASED ON AGE.

\begin{tabular}{|c|c|}
\hline Age & Percentage \\
\hline $17-24$ Year old & 38 \\
$25-32$ Year old & 6 \\
$33-40$ Year old & 37 \\
$>40$ Year old & 19 \\
\hline Total & 100 \\
\hline
\end{tabular}

TABLE V. RESPONDENTS' CHARACTERISTICS KJM “KIJANG MAS" MEATBALL BASED ON AGE.

\begin{tabular}{|c|c|}
\hline Age & Percentage \\
\hline $17-24$ Year old & 56 \\
$25-32$ Year old & 25 \\
$33-40$ Year old & 19 \\
$>40$ Year old & 0 \\
\hline Total & 100 \\
\hline
\end{tabular}

TABLE VI. RESPONDENTS' CHARACTERISTICS AJ MEATBALL BASED ON AGE.

\begin{tabular}{|c|c|}
\hline Age & Percentage \\
\hline $17-24$ Year old & 75 \\
$25-32$ Year old & 12 \\
$33-40$ Year old & 0 \\
$>40$ Year old & 13 \\
\hline Total & 100 \\
\hline
\end{tabular}

The results of the characteristics of consumers based on Religion in Table 7, Table 8 and Table 9 show that most consumers embrace Islam with a percentage of nearly 100 percent. Religion is an important consideration in the process of selecting foodstuffs to be consumed, starting from how to obtain raw materials, processing to packaging whether it is in accordance with the Shari'a so as to meet good food security.

TABLE VII. RESPONDENTS' CHARACTERISTICS OF YIKKO MEATBALL BASED ON RELIGION

\begin{tabular}{|c|c|}
\hline Religion & Percentage \\
\hline Islam & 88 \\
Christian & 6 \\
Hindu & 6 \\
\hline Total & 100 \\
\hline
\end{tabular}

TABLE VIII. RESPONDENTS' CHARACTERISTICS OF KJM "KIJANG MAS" MEATBALL BASED ON RELIGION

\begin{tabular}{|c|c|}
\hline Religion & Percentage \\
\hline Islam & 100 \\
Christian & \\
Hindu & \\
\hline Total & 100 \\
\hline
\end{tabular}

TABLE IX. RESPONDENTS' CHARACTERISTICS OF YIKKO MEATBALL BASED ON RELIGION

\begin{tabular}{|c|c|}
\hline Religion & Percentage \\
\hline Islam \\
Christian \\
Hindu & 100 \\
\hline Total & \\
\hline
\end{tabular}

The level of job for each individual is positively proportional to the level of income so that the higher the level of employment it is assumed that it has more income. In Table 10, Table 11 and Table 12 show that, most of the packaged meatball consumers are still students / college students with monthly income in level of Rp. 1,000,001 to Rp. 3,000,000 in accordance with the results of the research in Table 13, Table 14 and Table 15 which describe the characteristics of consumers based on income.

TABLE X. RESPONDENTS' CHARACTERISTICS OF YIKKO MEATBALL BASED ON JOBS

\begin{tabular}{|c|c|}
\hline Jobs & Percentage \\
\hline Students/college students & 25 \\
CIVIL SERVANTS & 0 \\
Private employee & 25 \\
Housewives & 25 \\
Retired & 0 \\
Business person & 25 \\
SOLDIER/POLICE OFFICER & 0 \\
\hline Total & 100 \\
\hline
\end{tabular}

TABLE XI. RESPONDENTS' CHARACTERISTICS OF KJM "KIJANG MAS" MEATBALL BASED ON JOBS

\begin{tabular}{|c|c|}
\hline Jobs & Percentage \\
\hline Students/college students & 50 \\
CIVIL SERVANTS & 6 \\
Private employee & 12 \\
Housewives & 19 \\
Retired & 0 \\
Business person & 13 \\
SOLDIER/POLICE OFFICER & 0 \\
\hline Total & 100 \\
\hline
\end{tabular}

TABLE XII. RESPONDENTS' CHARACTERISTICS OF AJ MEATBALL BASED ON JOBS

\begin{tabular}{|c|c|}
\hline Jobs & Percentage \\
\hline Students/college students & 50 \\
CIVIL SERVANTS & 0 \\
Private employee & 12 \\
Housewives & 13 \\
Retired & 0 \\
Business person & 25 \\
\hline
\end{tabular}




\begin{tabular}{|c|c|}
\hline Jobs & Percentage \\
\hline SOLDIER/POLICE OFFICER & 0 \\
\hline Total & 100 \\
\hline
\end{tabular}

TABLE XIII. RESPONDENTS' CHARACTERISTICS OF YIKKO MEATBALL BASED ON INCOME

\begin{tabular}{|c|c|}
\hline Income & Percentage \\
\hline < Rp. 1.000 .0000 & 6 \\
Rp. $1.000 .001-$ Rp. 3.000 .000 & 63 \\
Rp. 3.000 .001 - Rp. 6.000 .000 & 25 \\
Rp. 6.000 .001 - Rp. 10.000 .000 & 6 \\
>Rp. 10.000 .001 & 0 \\
\hline Total & 100 \\
\hline
\end{tabular}

TABLE XIV. RESPONDENTS' CHARACTERISTICS OF KJM "KIJANG MAS" MEATBALL BASED ON INCOME

\begin{tabular}{|c|c|}
\hline Income & Percentage \\
\hline < Rp. 1.000 .0000 & 31 \\
Rp. $1.000 .001-$ Rp. 3.000 .000 & 38 \\
Rp. 3.000.001 - Rp. 6.000 .000 & 31 \\
Rp. 6.000.001 - Rp. 10.000 .000 & 0 \\
>Rp. 10.000 .001 & 0 \\
\hline Total & 100 \\
\hline
\end{tabular}

TABLE XV. RESPONDENTS' CHARACTERISTICS OF AJ MEATBALL BASED ON INCOME

\begin{tabular}{|c|c|}
\hline Income & Percentage \\
\hline < Rp. 1.000.0000 & 12 \\
Rp. 1.000.001 - Rp. 3.000.000 & 50 \\
Rp. 3.000.001 - Rp. 6.000.000 & 38 \\
Rp. 6.000.001 - Rp. 10.000 .000 & 0 \\
>Rp. 10.000 .001 & 0 \\
\hline Total & 100 \\
\hline
\end{tabular}

The last level of education that has been taken by consumers has an influence on the decision to purchase packaged meatball products. In this study, most consumers have graduated from high school / vocational high school with a percentage of 56, 50 and 50 percent in Yikko, KJM "Kijang Mas" and AJ packaged beef meatballs. Education is a psychological factor that affects the type of food quality that will be consumed. This shows that a person's level of understanding and knowledge about the importance of nutritional content is influenced by the level of education [3].
TABLE XVI. RESPONDENTS' CHARACTERISTICS OF YIKKO MEATBALL BASED ON EDUCATION LEVEL

\begin{tabular}{|c|c|}
\hline Education level & Percentage \\
\hline PRIMARY/JUNIOR HIGH & 19 \\
SENIOR HIGH/VOCATIONAL & 56 \\
Diploma & 0 \\
UNDERGRADUATE & 25 \\
MASTER DEGREE & 0 \\
\hline Total & 100 \\
\hline
\end{tabular}

TABLE XVII. RESPONDENTS' CHARACTERISTICS OF KJM "KIJANG MAS" MEATBALL BASED ON EDUCATION LEVEL

\begin{tabular}{|c|c|}
\hline Education level & Percentage \\
\hline PRIMARY/JUNIOR HIGH & 38 \\
SENIOR HIGH/VOCATIONAL & 50 \\
Diploma & 6 \\
UNDERGRADUATE & 6 \\
MASTER DEGREE & 0 \\
\hline Total & 100 \\
\hline
\end{tabular}

TABLE XVIII. RESPONDENTS' CHARACTERISTICS OF AJ MEATBALL BASED ON EDUCATION LEVEL

\begin{tabular}{|c|c|}
\hline Education level & Percentage \\
\hline PRIMARY/JUNIOR HIGH & 37 \\
SENIOR HIGH/VOCATIONAL & 50 \\
Diploma & 0 \\
UNDERGRADUATE & 13 \\
MASTER DEGREE & 0 \\
\hline Total & 100 \\
\hline
\end{tabular}

B. Importance Performance Analysis of Packaged Beef Meatballs

Analysis of the level of importance and performance of a product, is important to formulate an effective marketing strategy for business behavior. The results of consumer appraisal of the interests and performance of packaged meatball products are processed using the IPA method, by using this method it is obtained which variables can satisfy and can not satisfy consumers and what variables are considered important and not important to consumers. After analyzing the level of importance and the level of performance of the attributes, the results are explained through the analysis of quadrant IPA or cartesian chart to see the position of each attribute in the four quadrants of IPA.

To find out the attributes that are considered important but their performance has not been satisfactory, the questionnaires were analyzed with Important and Performance Analysis (IPA) which measures the importance and performance of packaged meatball attributes so that the results are as shown in Table 22 below. 
TABLE XIX. IMPORTANCE LEVEL ON IPA OF PACKAGED MEATBALL PRODUCTS CALCULATION.

\begin{tabular}{|c|c|c|}
\hline Attributes & Importance Average Value of Packaged Meatball Products & Rank \\
\hline Halal Certification & 3,775 & 4 \\
\hline Composition & 3,75 & 6 \\
\hline Taste & 3,825 & 3 \\
\hline Quality & 3,75 & 5 \\
\hline Elasticity & 3,95 & 2 \\
\hline Price & 4,025 & 1 \\
\hline Total & 23,075 & \\
& 6 & \\
\hline
\end{tabular}

In Table 19 it can be seen that for all the attributes that exist, the Price has the highest value of interest with the value of 4.025 , in sequence, the attribute of elasticity with an interest value of 3.95 and for the third order it is Taste with an interest value of 3.825 . For numbers 4 to 6 , they are: Halal certification (3,775), Quality $(3,75)$, and Composition $(3,75)$. Furthermore, the performance of each product can be seen in Table 23 to Table 25 below

TABLE XX. IPA TOTAL CALCULATION OF YIKKO BEEF MEATBALL

\begin{tabular}{|c|c|c|c|c|}
\hline \multirow{2}{*}{ No } & \multirow{2}{*}{ Attributes } & \multicolumn{3}{|c|}{ Performance level } \\
\hline & & $\sum \mathbf{X i}$ & $\mathbf{n}$ & $\dot{\mathbf{x}}$ \\
\hline 1 & Halal Certification & 39 & 16 & 2 \\
\hline 2 & Composition & 53 & 16 & 3 \\
\hline 3 & Taste & 58 & 16 & 4 \\
\hline 4 & Quality & 60 & 16 & 4 \\
\hline 5 & Elasticity & 58 & 16 & 4 \\
\hline 6 & Price & 56 & 16 & 4 \\
\hline & & $\begin{array}{c}\text { Total } \\
\text { Total of Attributes } \\
\dot{\mathrm{x}} \\
\end{array}$ & & $\begin{array}{c}20,25 \\
6 \\
3,375 \\
\end{array}$ \\
\hline
\end{tabular}

In the calculation of the performance value of Yikko beef meatballs obtained as in Table 20 that, attribute of Price, Taste, Quality and Elasticity have the same performance value that is equal to 4 and for the composition has a performance level of 3 while halal certification has a performance level of 2 . With so obtained the value of $\dot{x}$ is 3.375 .

TABLE XXI. IPA TOTAL CALCULATION OF KJM “KIJANG MAS” BEEF MEATBALL

\begin{tabular}{|c|c|c|c|}
\hline \multirow[b]{2}{*}{ Attributes } & \multicolumn{3}{|c|}{ Performance level } \\
\hline & $\sum \mathbf{X i}$ & $\mathbf{n}$ & $\dot{\mathbf{x}}$ \\
\hline Halal Certification & 58 & 16 & 4 \\
\hline Composition & 62 & 16 & 4 \\
\hline Taste & 65 & 16 & 4 \\
\hline Quality & 60 & 16 & 4 \\
\hline Elasticity & 63 & 16 & 4 \\
\hline Price & 65 & 16 & 4 \\
\hline & $\begin{array}{c}\text { Total } \\
\text { Total of Attributes } \\
\dot{\mathrm{x}}\end{array}$ & & $\begin{array}{c}23,3125 \\
6 \\
3,885\end{array}$ \\
\hline
\end{tabular}

The next result is the calculation of the total performance value of the KJM "Kijang Mas" beef meatball which is presented in Table 21 which shows that, of all the attributes in KJM beef meatballs "Kijang Mas" has the interests contained in Table 19. As well as the results of performance calculations attribute after consuming KJM beef meatballs 
packaging "Kijang Mas" also has the same product performance value for all existing variables that have a value of 4 . This means that there are several attributes that show the same value with importance and even someof them show better performance or worse. And the value of $\dot{x}$ is 3.885

TABLE XXII. IPA TOTAL CALCULATION OF AJ BEEF MEATBALL

\begin{tabular}{|c|c|c|c|}
\hline \multirow{2}{*}{ Attributes } & $\sum \mathbf{X i}$ & $\mathbf{n}$ & \multicolumn{1}{c|}{ Performance Level } \\
\hline Halal Certification & 29 & 8 & \multicolumn{1}{c|}{} \\
\hline Composition & 29 & 8 & 4 \\
\hline Taste & 28 & 8 & 4 \\
\hline Quality & 30 & 8 & 4 \\
\hline Elasticity & 30 & 8 & 4 \\
\hline Price & 34 & 8 & 22,5 \\
\hline & Total & & 6 \\
\hline
\end{tabular}

In Table 22 shows the results of the performance calculation of AJ packaged meatball products. At the level of importance in Table 19, which attributes are considered important by consumers. Then assessing the performance of the attributes in the AJ packaged meatballs. The performance results show that the average value of the performance level between 3 and 4 with the average number of attribute performance is 22.5 with the total of attributes are 6 .

TABLE XXIII. RESULTS OF IMPORTANCE AND PERFORMANCE MATRIX ALL PACKAGED MEATBALL PRODUCTS

\begin{tabular}{|c|c|c|c|c|c|c|}
\hline \multirow[t]{2}{*}{ Quadrant I } & \multicolumn{2}{|c|}{ Quadrant II } & \multicolumn{2}{|r|}{ Quadrant III } & \multicolumn{2}{|r|}{ Quadrant IV } \\
\hline & $\begin{array}{l}1 \\
2 \\
3\end{array}$ & $\begin{array}{c}\text { Taste (4) } \\
\text { Elasticity (4) } \\
\text { Price (4) }\end{array}$ & 1 & $\begin{array}{c}\text { Halal certification (2) } \\
\text { Composition (3) }\end{array}$ & 1 & Quality (4) \\
\hline \multicolumn{7}{|c|}{ IPA Result On KJM “Kijang Mas” Packaged Meatball } \\
\hline \multirow[t]{2}{*}{ Quadrant I } & \multicolumn{2}{|c|}{ Quadrant II } & \multicolumn{2}{|r|}{ Quadrant III } & \multicolumn{2}{|r|}{ Quadrant IV } \\
\hline & $\begin{array}{l}1 \\
2\end{array}$ & $\begin{array}{c}\text { Taste (4) } \\
\text { Elasticity (4) } \\
\text { Price (4) } \\
\end{array}$ & & & $\begin{array}{l}1 \\
2 \\
3 \\
\end{array}$ & $\begin{array}{c}\text { Halal certification (4) } \\
\text { Composition (4) } \\
\text { Quality (4) }\end{array}$ \\
\hline \multicolumn{7}{|c|}{ IPA Result On AJ Packaged Meatball } \\
\hline \multirow[t]{2}{*}{ Quadrant I } & \multicolumn{2}{|c|}{ Quadrant II } & \multicolumn{2}{|r|}{ Quadrant III } & \multicolumn{2}{|r|}{ Quadrant IV } \\
\hline & $\begin{array}{l}1 \\
2\end{array}$ & $\begin{array}{c}\text { Taste (4) } \\
\text { Elasticity (4) } \\
\text { Price (4) }\end{array}$ & & & $\begin{array}{l}1 \\
2 \\
3\end{array}$ & $\begin{array}{c}\text { Halal certification (4) } \\
\text { Composition (4) } \\
\text { Quality (4) }\end{array}$ \\
\hline
\end{tabular}


Important and Performance Matrix is needed to see the position of the 6 packaged meatball attributes that are obtained based on the score of importance and performance level score based on 40 respondents, so that it can be related between the importance of these attributes and the reality. So that later it can be focused on efforts that must be implemented based on 4 quadrants in the IPA diagram.

Table 4.7 is the result of the calculation of the IPA method which shows that, the Yikko, KJM "Kijang Mas" and the AJ beef meatballs have attributes that are in Quadrant I, Quadrant II, Quadrant III and Quadrant IV.

In quadrant II there is a number of packaging meatballs attributes of the Yikko brand, KJM "Kijang Mas" and AJ with the attributes of all brands are same, they are Taste, Elasticity and Price. So that these attributes are considered to be achievable by consumers so that their performance need to be maintained and if possible, should be improved. because the actual level of performance is generally in line with customer expectations.

Attributes in quadrant III are shown by Yikko packaged meatballs are as follow: Halal certification, and Composition. Which mean, attributes in quadrant III are attributes that are less important or have a low influence on consumers, and the level of performance of these attributes is still low. Although the attributes in this quadrant also need to be improved, but the performance improvement is not a top priority, because if the performance of attributes in quadrant III are improved, it will not significantly increase total customer satisfaction. Therefore, the most important attributes to be improved are attributes that are in quadrant I, because they are considered important by consumers.

Attributes in quadrant IV are attributes of Yikko, KJM "Kijang Mas" and the AJ packaged meatball products. In Yikko meatballs there is Quality attribute while in other packaged meatballs, there are 4 attributes of KJM "Kijang Mas" meatballs in the quadrant, they are: Halal Certification, Composition and Quality. Whereas in the AJ meatballs there are attributes that exist in quadrant IV, they are: Halal Certification, Composition and Quality. So that these attributes have a very good level of performance, although it has a low level of importance. These attributes' performance need to be reconsidered because they are too excessive in their implementation. So what needs to be done is to manage the existing investment. So that it can be contributed optimally and proportionally according to the priorities that have been determined, namely the attributes that are considered important by consumers, and their performance has not been satisfying so that performance improvement is needed.

The level of importance will influence consumer decisions in buying and consuming meatball products. Improvement of attributes performance that are considered important will increase total satisfaction higher than the improvement of attributes performance that are considered not so important by consumers. The higher the value obtained, the more important the attribute is. Information about the importance of meatball attributes obtained through questionnaires distributed by determining the quality using a Likert scale.

\section{Relation between Meatball Attributes and Consumer Preference}

In order to be able to see overall whether Price, Halal, Composition, Taste, Quality and Elasticity attributes have a significant relation, the Chi-Square test is used. Chi Square test is significant at 5 percent $(0.05)$.

There is one variable that has no relation with the frequency of purchase of Yikko packaged meatballs in Table 24 about the relation of several Yikko meatball variables with consumer preferences, it is Composition with Sign of 0.052 bigger than 0.050 . While the variable that has the most relation is the variable Price with a sign value of 0.006 is much smaller than the value of 0.050 .

TABLE XXIV. RELATION OF YIKKO MEATBALL VARIABLES WITH CONSUMER PREFERENCE

\begin{tabular}{|c|c|c|c|c|c|}
\hline No & Variable & & \multicolumn{2}{c|}{ df } & 4 \\
\hline $\mathbf{1}$ & Price & 0,006 & 0,05 & 9 & Yes \\
\hline $\mathbf{2}$ & Halal certification & 0,035 & 0,05 & 6 & Yes \\
\hline $\mathbf{3}$ & Composition & 0,052 & 0,05 & 4 & No \\
\hline $\mathbf{4}$ & Taste & 0,022 & 0,05 & 4 & Yes \\
\hline $\mathbf{5}$ & Quality & 0,012 & 0,05 & 2 & Yes \\
\hline $\mathbf{6}$ & Elasticity & 0,020 & 0,05 & 2 & Yes \\
\hline
\end{tabular}

The composition has the highest Sign value, and the value is more than 0.05 so that it does not have a significant relation to consumer preferences for packaged beef meatball products. This is because consumers do not make composition as a top priority in terms of purchasing, not even noticed. According to the results of the interview, it was found that consumers pay attention to taste and elasticity other than price. 
TABLE XXV. RELATION OF KJM MEATBALL VARIABLES WITH CONSUMER PREFERENCE

\begin{tabular}{|c|c|c|c|c|c|}
\hline No & Variable & \multicolumn{3}{c|}{ df } & \multicolumn{2}{c|}{ Relation } \\
\hline $\mathbf{1}$ & Price & 0,028 & 0,05 & 9 & Yes \\
\hline $\mathbf{2}$ & Halal certification & 0,128 & 0,05 & 9 & No \\
\hline $\mathbf{3}$ & Composition & 0,115 & 0,05 & 9 & No \\
\hline $\mathbf{4}$ & Taste & 0,034 & 0,05 & 6 & Yes \\
\hline $\mathbf{5}$ & Quality & 0,035 & 0,05 & Yes \\
\hline $\mathbf{6}$ & Elasticity & 0,033 & 0,05 & 4 & Yes \\
\hline
\end{tabular}

Based on Table 25 the results show that there are 6 variables that are associated with the frequency of purchase of KJM beef meatballs "Kijang Mas". There are 2 variables that have no relation with a Sign value more than 0.050 , they are Halal Certification and Composition, each of which has a Sign value of 0.128 and 0.115 . While the variable that has the smallest Sign value is the price of 0.028 , much smaller than the value of 0.050 . So it has a high relation with the frequency of purchasing KJM beef meatballs "Kijang Mas". So, it can be concluded that, the KJM brand
"Kijang Mas" packaged beef meatball consumers does not pay attention to the halal certification of meatballs they purchased. This is not in accordance with the characteristics of consumers who are all Muslim. In fact, most consumers ignore the halal of the product they consumed.

As for other attributes, the KJM "Kijang Mas" packaged beef meatball show a higher relationship to consumer preferences compared to halal certification which is very important to the quality of meatballs for physical and spiritual health.

TABLE XXVI. RELATION OF AJ MEATBALL VARIABLES WITH CONSUMER PREFERENCE

\begin{tabular}{|c|c|c|c|c|c|}
\hline No & Variable & \multicolumn{2}{c|}{ Df } & 2 & Yelation \\
\hline $\mathbf{1}$ & Price & 0,018 & 0,05 & 8 & No \\
\hline $\mathbf{2}$ & Halal certification & 0,315 & 0,05 & 4 & No \\
\hline $\mathbf{3}$ & Composition & 0,715 & 0,05 & 4 & Yes \\
\hline $\mathbf{4}$ & Taste & 0,014 & 0,05 & 4 & Yes \\
\hline $\mathbf{5}$ & Quality & 0,040 & 0,05 & 4 & Yes \\
\hline $\mathbf{6}$ & Elasticity & 0,021 & 0,05 & 4 \\
\hline
\end{tabular}

In Table 26, the results obtained from the calculation with the Chi Square method which have 2 variables that do not have significant relations to the frequency of purchase, they are Halal Certification and Composition with a Sign value of 0.315 and 0.715 much more than the value of 0.050 so that they do not have relation in purchasing of AJ beef meatballs. For the value of the Sign in Variable which has the most relation to the frequency of purchase of AJ beef meatballs, which is Taste with a Sign value of 0.014 is much smaller than 0.050 . So it has a close relation to the process of purchasing AJ Beef Meatballs.

AJ beef meatballs is a packaged meatball that does not have a halal label on the packaging, but in fact all consumers who consume the product are Muslim. So that there are still many Muslim consumers who do not even pay attention to the quality of the product to be consumed based on the origin of the meatball processing. The things that are most considered only in terms of price, taste and elasticity. Islam teaches Muslims to consume halal products. Based on Islamic law there are three categories of products for Muslims namely halal, haram and mushbooh. Halal in Arabic means permissible, usable, and valid according to law (Yusoff, 2004). The opposite of halal is haram which means it is not permitted, cannot be used and is not legally valid. Whereas mushboooh (syubha, shubhah and mushbu) means black and white, it is still questionable and doubtful therefore it should be avoided.

Halal certification is a guarantee of security for a Muslim consumer to be able to choose foods that are good for him and in accordance with religious rules. Food products that have halal certification are products that in the processing process meet standards in safety and cleanliness (LYes, 2009). According to the Head of Religion Minister of Religion R.I number 518 stated that halal certification is a written fatwa stating the halalness of a food product issued by the Indonesian Institute of Food Studies, Drugs and Cosmetics of the Indonesian Ulema Council (LPPOM MUI). Halal certification in Indonesia is issued officially by the MUI which indicates that the product has passed the halal test. Products that have halal certification are products that have been tested in halal and can be consumed by Muslims. Products that have halal certification are proven by the stamp of halal logos on product packaging.

Table 27 is the result of Chi-Square calculation of all packaged meatball products, which are Yikko, KJM "Kijang Mas" and AJ. The results show that Yikko beef meatball 
products from the overall attributes indicate that there is one attribute that has no relation with consumer preferences, it is Composition. This means that the attributes of composition do not become thing that can affect consumers' choices in buying. And the thing that is most considered by consumers is in term of price. The price shows the highest relation by having a significance value of 0.006 much smaller than 0.05 so that the relation is very close with the consumer's decision to buy Yikko packaged beef meatball.

TABLE XXVII. RESULT OF CHI SQUARE ALL PACKAGED MEATBALL PRODUCTS

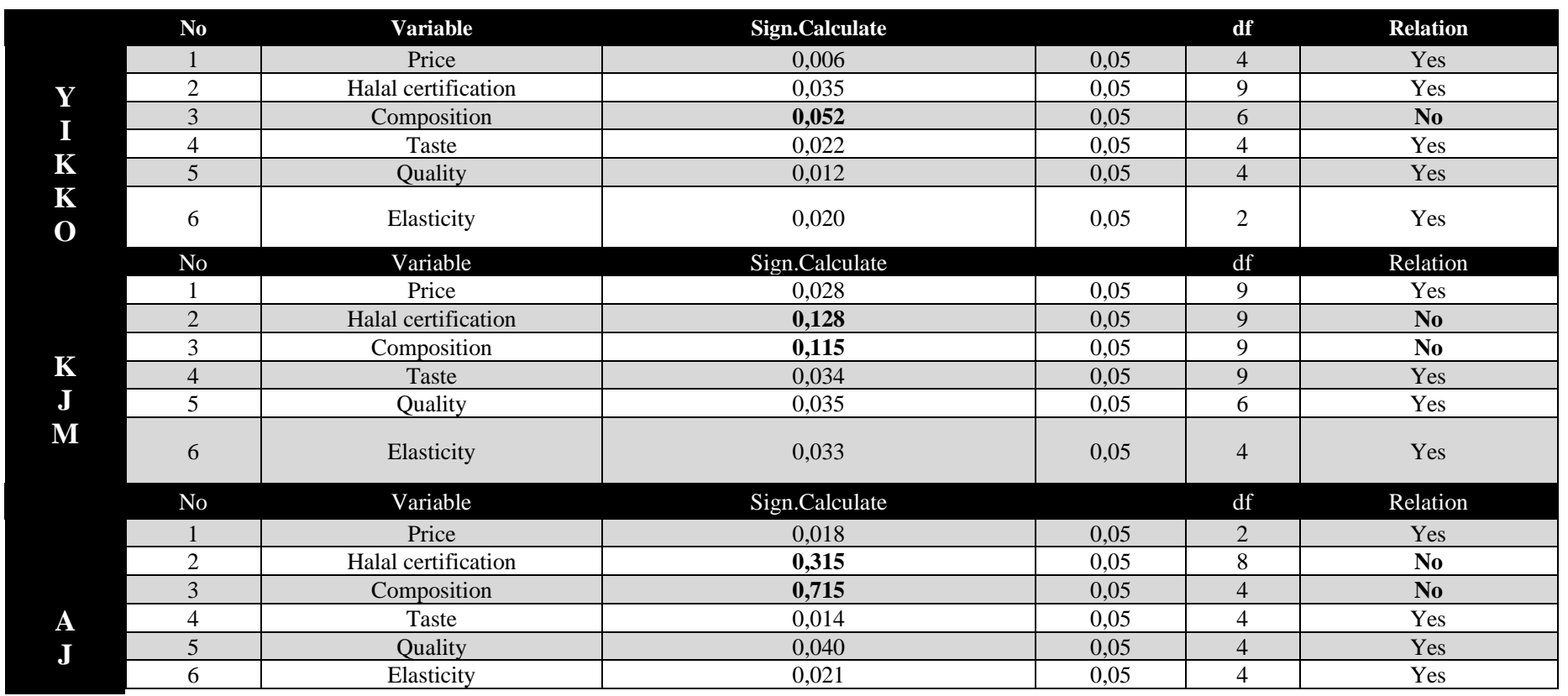

KJM beef meatballs "Kijang Mas" its results show that, there are two attributes that have no relation to consumer preferences, they are the attributes of the composition and Halal certification, means that these attributes are not taken into consideration by consumers in buying products that will be chosen for their own consumption or by family members. The halal certification attribute is considered not to have a close relation by consumers. This can be affected because the Wonokromo traditional market is a segmented market among those who have middle to lower income so that the most considered thing in purchasing some products includes beef meatballs packaging, is price. Price becomes very important according to consumers rather than the halal certification on the packaging meatball products. Most consumers do not pay attention and are careful with the ingredients used by the producers in the meatball mixture. So that makes halal certification is not a priority attribute by consumers in buying packaged meatball products [4].

The relation in the AJ packaged meatball attributes with preference that there are several attributes that do not have a significant relation to consumer preferences. These attributes are halal certification and composition. It can be assumed that consumers' income can influence consumers in deciding which product to buy. Wonokromo traditional market, which is dominated by consumers with lowermiddle level of income, where some of the qualities of meatball products are considered not important according to consumers. The most considered things are the attributes of Taste and Price. In the Taste attribute has a significance value of 0.014 is much smaller than 0.05 . As well as the price attribute has a significance value of 0.018 much smaller than 0.05. So it has a significant relation to consumer preferences. Some of the things that need to be considered by the next researchers are the need to have criteria more specific to some of the attributes used and to have a more accurate assessment using scale as needed. and, it is expected that the respondents used are respondents who visit more than one month period so that they are able to provide more detailed assessment that could improve the quality of the performance of the packaged meatball product. 


\section{IV.CONCLUSION}

Based on the analysis of consumer preferences in the traditional market of Wonokromo, the following conclusions are obtained:

1. There are several similarities of the characteristics of beef meatball consumers, they are: most of consumers are women, which aged 17-24 years and Islam while their jobs are students, private employees, housewives and entrepreneurs. With income level of Rp. 1,000.001 - Rp. $3,000,000$ and their last level of education, is high school / vocational school

2. Based on the results of the study, it is found that the most important attributes according to consumers are price, elasticity, taste, halal certification and quality, then most neglected attribute by consumers, is composition. This is because the traditional Wonokromo is a traditional market which its consumers have middle to lower level of income. So Price is the most important attribute according to consumers. For the highest attribute performance on Yikko product are as follow: Taste, Elasticity, Price and Quality. On KJM product "Kijang
Mas" also has same average overall performance. And on AJ products, the entire attribute shows good performance with one attribute that has the same value.

3. Based on the results of the study, it is found that the attributes of the packaged meatballs are significantly related to consumer preferences, are Price, Taste, Elasticity, and Quality. Price is the most considered attribute by consumers in buying due to income factor as they are classified in middle to lower level of income in Wonokromo traditional market, Surabaya.

\section{REFERENCES}

[1] D. Priyatno, "Easy and Quick Techniques to Conduct Research Data Analysis with SPSS and FAQs," Gaya Media, Yogyakarta, 2010.

[2] Roscoe, "Research Methods For Business. In :Sugiyono. (2013). Quantitative, Qualitative, R\&D Research Methods," Bandung: Penerbit Alfabeta, 1982.

[3] Sugiyono, "Administration Research Methods, " Bandung: Alfabeta, 2005 .

[4] J. Supranto, "Research Method: Applied in Marketing," Jakarta: PT Rineka Cipta, 2003. 